\title{
Ground-based Remote Sensing of Total Columnar CO2, CH4, and CO using EM27/SUN FTIR spectrometer at a suburban location in India and validation of Sentinel-5p/TROPOMI
}

This paper was downloaded from TechRxiv (https://www.techrxiv.org).

\section{LICENSE}

CC BY 4.0

\section{SUBMISSION DATE / POSTED DATE}

08-02-2022 / 22-02-2022

\section{CITATION}

Sagar, Vijay Kumar; P, Mahesh; D.V., Mahalakshmi; K.S., Rajan; M.V.R, Sesha Sai; Hase, Frank; et al. (2022): Ground-based Remote Sensing of Total Columnar CO2, CH4, and CO using EM27/SUN FTIR spectrometer at a suburban location in India and validation of Sentinel-5p/TROPOMI. TechRxiv. Preprint. https://doi.org/10.36227/techrxiv.19137242.v1

$\mathrm{DOI}$ 


\title{
Ground-based Remote Sensing of Total Columnar $\mathrm{CO}_{2}, \mathrm{CH}_{4}$, and $\mathrm{CO}$ using EM27/SUN FTIR spectrometer at a suburban location in India and validation of Sentinel-5p/TROPOMI
}

\author{
Vijay Kumar Sagar ${ }^{1}$, Mahesh $P^{1,2}$, Mahalakshmi D.V ${ }^{3}$, Rajan K.S ${ }^{2}$, Sesha Sai M.V.R ${ }^{4}$, Frank Hase ${ }^{5}$, Darko \\ Dubravica $^{5}$, Mahesh Kumar Sha ${ }^{6}$.
}

\begin{abstract}
Greenhouse gasses (GHGs) play an important role in controlling local air pollution as well as climate change. In the present study, we retrieved column-averaged dry-air $(X)$ mole fractions of carbon dioxide $\left(\mathrm{CO}_{2}\right)$, methane $\left(\mathrm{CH}_{4}\right)$, and carbon monoxide (CO) using a ground-based EM27/SUN Fourier Transform Infrared Spectrometer (FTIR). The EM27/SUN spectrometers are widely in use in the COllaborative Carbon Column Observing Network (COCCON). The PROFFAST software provided by COCCON has been used to analyze the measured atmospheric solar absorption spectra. In this paper, the diurnal variation and the time series of daily averaged $\mathrm{XCO}_{2}$, $\mathrm{XCH}_{4}$, and $X \mathrm{XO}$ covering the period December 2020 to May 2021 are analyzed. The maximum values of $\mathrm{XCO}_{2}, \mathrm{XCH}_{4}$, and $\mathrm{XCO}$ are observed to be $420.57 \mathrm{ppm}, 1.93 \mathrm{ppm}$, and $170.40 \mathrm{ppb}$ respectively. Less diurnal $\left(\mathrm{XCO}_{2} \sim 0.44 \mathrm{ppm} ; \mathrm{XCH}_{4}=0.004 \mathrm{ppm}\right.$, and $\mathrm{XCO}=4.84 \mathrm{ppb}$ ) but clear seasonal changes are observed during the study period. The $\mathrm{XCH}_{4}$ and $\mathrm{XCO}$ from the Sentinel5Precursor (S5P)/TROPOspheric Monitoring Instrument (TROPOMI) are compared against the EM27/SUN retrievals. The correlation coefficient ' $r$ ' between the EM27/SUN retrieved $\mathrm{XCH}_{4}$ and $X \mathrm{CO}$ against S5P/TROPOMI are 0.75 and 0.94 respectively.
\end{abstract}

Index Terms- Greenhouse Gases, EM27/SUN, S5P/TROPOMI.

\section{INTRODUCTION}

Anthropogenic activities entail the release of various trace gasses into the atmosphere, mainly due to industrialization, acceleration of economy, and power generation [1]. Though there are many greenhouse gasses (GHGs), atmospheric carbon dioxide $\left(\mathrm{CO}_{2}\right)$ and methane $\left(\mathrm{CH}_{4}\right)$ are the leading contributors to anthropogenic global warming [2]. In India, the total emissions rose to $2.52 \mathrm{Gt} \mathrm{CO}_{2}$ year $^{-1}$ in 2021 compared to the emissions (2.32 $\mathrm{Gt} \mathrm{CO}_{2}$ year $^{-1}$ ) in 2014. Coal fire-based power generation is a major anthropogenic activity contributing about $54 \%$ of the electricity produced in India [3]. Due to its steady growth in the atmosphere and uncertainty of source/sink, anthropogenic $\mathrm{CH}_{4}$ concentration has attracted the interest of the research community over the last decade [4]. Long-term measurements from the National Oceanic and Atmospheric Administration (NOAA) reveal an annual $\mathrm{CH}_{4}$ increase of $8 \mathrm{ppb}$ year $^{-1}$ [5] while the present study site showed 10 ppb year ${ }^{-1}$ [6]. Carbon monoxide (CO) is an ozone precursor gas that also affects climate due to its role in the formation of $\mathrm{OH}$ radicals in the atmosphere [7]. $\mathrm{CO}$ is emitted mostly as a result of incomplete combustion in urban/industrial fossil fuel, biofuel, and biomass combustion. Because atmospheric $\mathrm{CO}$ is a serious pollutant, it is vital to investigate the impact of local and transported sources on air quality. Global $\mathrm{CO}_{2}$ and $\mathrm{CH}_{4}$ column measurements are especially useful for understanding regional sources and sinks [13], [14]. The satellite-based $X_{C_{2}}$ data with accuracy and precision of 1-2 ppm has the potential to improve understanding of surface fluxes [10]. At present, several GHGs dedicated missions are in orbit namely the Greenhouse Gases Observing Satellite (GOSAT-1 [9], [11], GOSAT-2 [12], the Orbiting Carbon Observatory-2 (OCO-2), and OCO3 [13] [14] and the Copernicus Sentinel-5 Precursor (S5P)/TROPOspheric Monitoring Instrument (TROPOMI) [15]. As[15]result, combining ground and space-based remote sensing has become a potent tool for studying GHG spatial and temporal variability. The most important source of GHG reference validation data is the ground-based Fourier Transform Infrared (FTIR) from Total Carbon Column Observing Network (TCCON) [16], which has been recently complemented by the portable EM27/SUN FTIR spectrometers from COCCON (COllaborative Carbon Column Observing Network) [17]. The measured near-infrared spectra are used to calculate dry-air column-averaged trace gas abundances.

In the tropics, columnar observations of GHGs are especially important since convection is always prevalent, and as a result, flux patterns are only weakly visible in surface measurements. In the present work, solar spectra collected at NRSC, Shadnagar, a suburban site in India using an EM27/SUN spectrometer are presented and discussed. Shadnagar is a tropical station located at latitude $17.0365^{\circ} \mathrm{N}$, longitude $78.1851^{\circ} \mathrm{S}$, altitude $540 \mathrm{~m}$ a.s.1. The observations were performed from $7^{\text {th }}$ December 2020 to $3^{\text {rd }}$ May 2021.

This study is the first of its kind over the Indian subcontinent. Shadnagar is a tropical station, observations were performed from $7^{\text {th }}$ December 2020 to $3^{\text {rd }}$ May 2021. The present study also includes a comparison of the ground-based retrievals of $\mathrm{XCH}_{4}$ and $\mathrm{XC}$ with the Sentinel-5P/TROPOMI $X \mathrm{CH}_{4}$ and $X \mathrm{CO}$ retrievals during the study period. 
$>$ REPLACE THIS LINE WITH YOUR MANUSCRIPT ID NUMBER (DOUBLE-CLICK HERE TO EDIT) <

\section{DATA AND METHODOLOGY}

EM27/SUN: The spectrometer has been developed by the Karlsruhe Institute of Technology, Germany, in collaboration with Bruker Optics as described in [17]. It covers a spectral range of $4,000-10,000 \mathrm{~cm}^{-1}(1.0 \mu \mathrm{m}$ to $2.5 \mu \mathrm{m})$ with spectral resolution of $0.5 \mathrm{~cm}^{-1}$ (maximum optical path distance amounts to $1.8 \mathrm{~cm}$ ). It records near-infrared (NIR) solar spectra using Indium Gallium Arsenide (InGaAs) detectors. While $\mathrm{XCO}_{2}$ and $\mathrm{XCH}_{4}$ are covered by the main (shortwave) detector, XCO is covered by the auxiliary (longwave) detector [18]. We have used PROFFAST [19] which is a non-least square spectral algorithm to retrieve the species concentrations. The spectral windows for $\mathrm{CO}_{2}, \mathrm{CH}_{4}$, and $\mathrm{CO}$ are $6173-6390 \mathrm{~cm}^{-1}$, 5897-6145 $\mathrm{cm}^{-1}$, and $4233-4290 \mathrm{~cm}^{-1}$ respectively.

During the study period, a total of 19494 observations were taken from $7^{\text {th }}$ December 2020 to $3^{\text {rd }}$ May 2021 covering 74 clear sky days from morning 09:20 Indian Standard Time (IST) to till evening 16:45 IST. Pre-processing and trace gas retrievals followed by post-processing are the two processes in the data analysis chain (fig 1). The DC correction, Fast Fourier Transformation including a phase correction scheme and a spectral resampling are performed first for generating spectra from the raw interferograms. The default modulation efficiency (0.983) of an average COCCON spectrometer was used for the trace gas analysis. In the post-processing, the retrieved column values are divided by the dry air column (derived from the co-observed oxygen column) and air massindependent and air mass-dependent corrections are taken into account for generating the final $X_{\text {gas }}$ values. The initial volume files as provided by TCCON (referred to as map-files), which contain the a-priori mixing ratio profiles of the relevant gases and the temperature profiles were used for the trace gas analysis. The column-averaged amount of dry air (Xair), which measures the instrument's stability, is found $0.9888 \pm 0.008$ during the study period. The daily average of Xair was in the range of 0.9856 to 0.9924 (Fig 1b), indicating excellent stability of the spectrometer over the observation period.

Sentinel-5p retrieved $X \mathrm{CH}_{4}$ and $X \mathrm{CO}$ : Sentinel5P/TROPOMI instrument was switched to a better spatial resolution of $5.5 \mathrm{~km}$ (across-track) X $7 \mathrm{~km}$ (along-track) from $6^{\text {th }}$ August 2019. For CO, the processing baseline, product versions, and quality limitations are described in the Product Readme File (PRF) [20]. We have used TROPOMI CO associated with a quality assurance value (qa_value) $>0.5$ as recommended in PRF. These criteria separated the retrievals performed under clear sky and clear sky like observations (qa_value $=1$, Cloud optical thickness $<0.5$ and cloud height $<$ $500 \mathrm{~m}$ ) and cloudy conditions (qa_value $=0.7$, Cloud optical thickness $\geq 0.5$ and cloud height $<5000 \mathrm{~m}$ ). S5P L2 used in the study provides a total vertically integrated column of $\mathrm{CO}$ $\left(T C_{C O}\right)$, therefore $X \mathrm{CO}$ is calculated by taking the ratio of $T C_{C O}$ and a total vertically integrated column of dry air $\left(\mathrm{TC}_{\mathrm{dry}}\right.$ air). Since the total column of $\mathrm{O}_{2}$ and $\mathrm{N}_{2}$ is not available, $\mathrm{TC}_{\text {dry }}$ air is calculated from the surface pressure $\left(\mathrm{P}_{\mathrm{s}}\right)$ and vertically integrated water column $\left(\mathrm{TC}_{\mathrm{H} 2 \mathrm{O}}\right)$ from the equation (1).

$X C O=\frac{T C_{C O}}{T C_{d r y, a i r}}=\frac{T C_{C O}}{P_{S} /\left(g \times m_{\text {dry air }}\right)-T C_{\mathrm{H}_{2}} \mathrm{O} \times\left(m_{\mathrm{H}_{2} \mathrm{O}} / m_{\text {dry air }}\right)}-\cdots-$ (1) Where $\mathrm{g}=9.82 \mathrm{~m} \cdot \mathrm{s}^{-2}$ is the column-average gravity acceleration and $\mathrm{m}_{\mathrm{H} 2 \mathrm{O}}=0.01801528 \mathrm{~kg} \mathrm{~mol}^{-1}$ is the molecular mass of $\mathrm{H}_{2} \mathrm{O}$, $\mathrm{m}_{\text {dry, air }}=0.0289644 \mathrm{~kg} \mathrm{~mol}^{-1}$ is the molecular mass of dry air [21]. The S5P pixels within the radius of $100 \mathrm{~km}$ around the observation site are taken for comparison. The ground-based EM27/SUN spectrometer observations are taken within an hour of the satellite overpass. In the same way, the radius of $100 \mathrm{~km}$ was taken for the comparison of $\mathrm{CH}_{4}$ [21], [22]. We have used TROPOMI $\mathrm{XCH}_{4}$ biased corrected data associated with a quality assurance value (qa_value $>0.5$ ) similar to S5P $\mathrm{CO}$ as recommended in $\mathrm{CH}_{4} \mathrm{PRF}$ [23]. The $\mathrm{S} 5 \mathrm{P} \mathrm{CH}_{4}$ is already given in the volume mixing ratio hence compared directly against EM27/SUN retrieved $X \mathrm{CH}_{4}$. Details of the data used in the present study are summarized in Table 1.

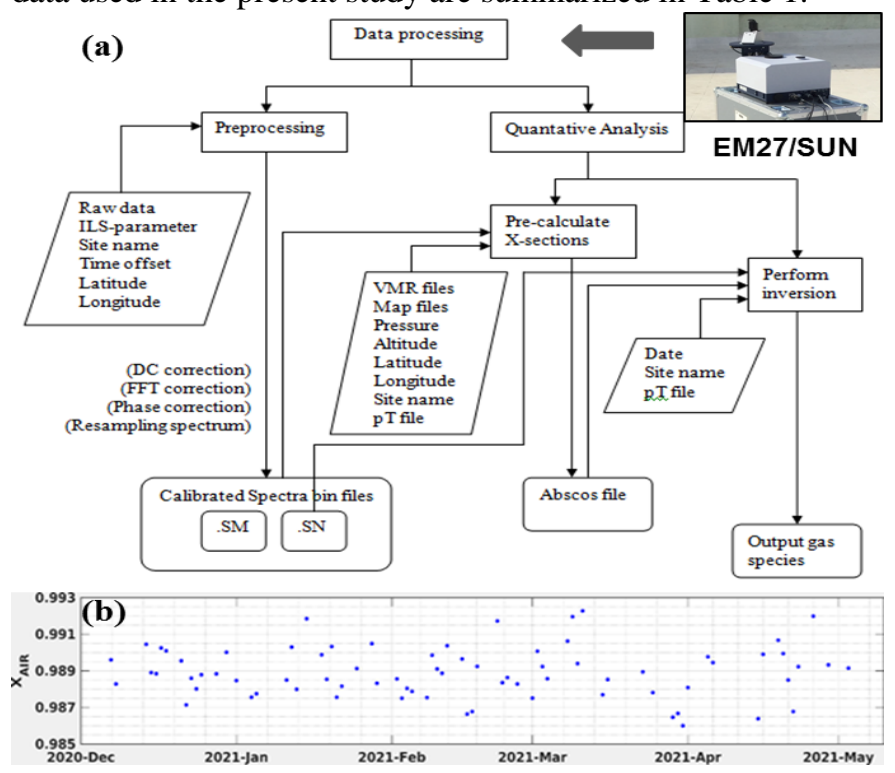

Figure 1. a) EM27/SUN Spectrometer data analysis using PROFFAST.b) Xair during the observational period.

\begin{tabular}{|l|l|l|l|}
\hline $\begin{array}{l}\text { Para- } \\
\text { meters }\end{array}$ & $\begin{array}{l}\text { Data } \\
\text { sources }\end{array}$ & Resolution & DOI \\
\hline $\begin{array}{l}X \mathrm{CO}_{2}, X \mathrm{CH}_{4}, \text { and } \\
X \mathrm{CO}\end{array}$ & EM27/SUN & $\begin{array}{l}\text { Point location } \\
\left(17.0365^{\circ} \mathrm{N},\right. \\
78.1851^{\circ} \mathrm{E}, 540 \\
\mathrm{~m})\end{array}$ & NA \\
\hline$X \mathrm{CH}_{4}$ & $\begin{array}{l}\text { S5P L2 } \\
\text { version } \\
01.04 .00\end{array}$ & $5.5 \mathrm{~km} \mathrm{x} \mathrm{7km}$ & {$[3]$} \\
\hline$X \mathrm{CO}$ & $\begin{array}{l}\text { S5P L2 } \\
\text { version } \\
01.04 .00\end{array}$ & $5.5 \mathrm{~km} \mathrm{x} \mathrm{7km}$ & {$[25]$} \\
\hline
\end{tabular}

Table 1. Details of $\mathrm{XCO}_{2}, \mathrm{XCH}_{4}$, and $\mathrm{XCO}$ used during the study period. 
$>$ REPLACE THIS LINE WITH YOUR MANUSCRIPT ID NUMBER (DOUBLE-CLICK HERE TO EDIT) <

\section{RESULTS AND DISCUSSIONS}

Diurnal variation: Figure 2 (a) depicts the diurnal variability of $\mathrm{XCO}_{2}, \mathrm{XCH}_{4}$, and $\mathrm{XCO}$ over the study period, while 2(b) depicts the deviation (daily mean-value) of $\mathrm{XCO}_{2}$ and $X \mathrm{CO}$. The variability in $\mathrm{XCO}_{2}$ is ranged from $0.20 \mathrm{ppm}$ to $1.80 \mathrm{ppm}$ during diurnal time windows, showing that there is a less diurnal effect on $\mathrm{XCO}_{2}$. When compared to $\mathrm{XCO}_{2}$, however, $X \mathrm{CO}$ has a higher diurnal variation. This could mainly be shaped by the local environmental conditions and small-scale industries around the study site. The major sources of $\mathrm{CO}$ are the oxidation of $\mathrm{CH}_{4}$, industrial activities such as the combustion process, biomass burning, and the oxidation of non-methane hydrocarbons [26]. The major sink of $\mathrm{CO}$ is oxidation with hydroxyl radical $(\mathrm{OH})$. Maximum and minimum $X \mathrm{CO}_{2}, X \mathrm{CH}_{4}$, and $\mathrm{XCO}$ are summarized in table 2 .

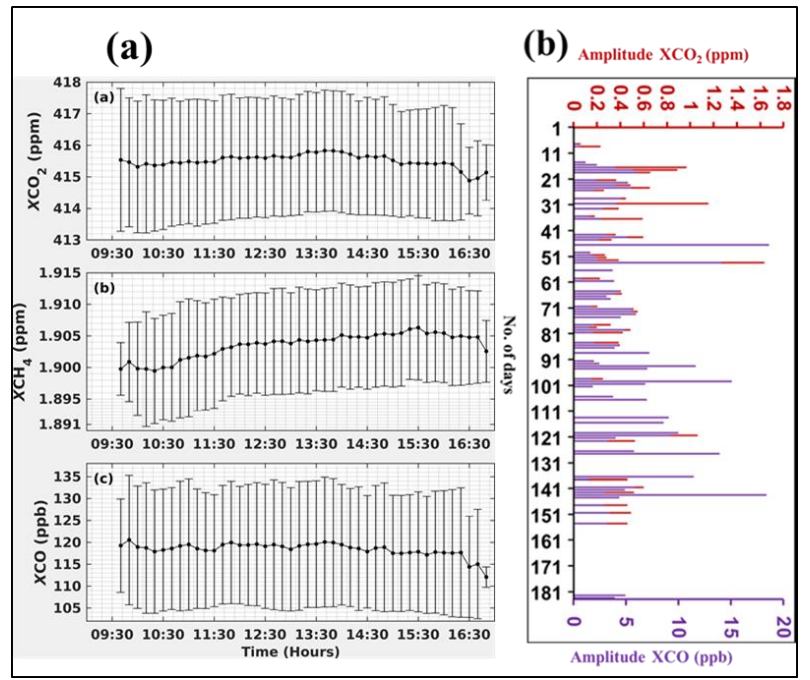

Figure 2. The diurnal variation of $\mathrm{XCO}_{2}, \mathrm{XCH}_{4}$, and $\mathrm{XCO}$ respectively during the study period and $(b)$ the diurnal amplitude of $\mathrm{XCO}_{2}$ and $\mathrm{XCO}$.

Daily and seasonal variation: The time series analysis in Figure 3 shows clear seasonal changes in the $\mathrm{XCO}_{2}, \mathrm{XCH}_{4}$, and $X \mathrm{CO}$ (Fig 4b-d) during the study period. The concentrations are higher in the pre-monsoon season (March-April-May) than in winter (December-January-February). In winter, there was less $\mathrm{XCO}_{2}$ than in the pre-monsoon, which could be due to reduced $\mathrm{CO}_{2}$ assimilation due to lower temperatures and solar radiation [6]. From winter to pre-monsoon, the $\mathrm{XCH}_{4}$ shows less seasonality, with a maximum amplitude change of 0.014 ppm. The spatial distribution of surface fluxes and atmospheric transport at the synoptic-scale are substantially responsible for the variability of $X_{C_{2}}$ and $X_{C_{4}}$. With an amplitude variation of $\sim 18 \mathrm{ppb}$, dry column-averaged $\mathrm{CO}$ concentration indicates very considerable seasonality across the study period. This variation could be attributed to $\mathrm{CO}$ emissions from fossil fuels, biomass burning, and industrial production on a daily basis. In comparison to winter, there is a higher surge in fire activity during the pre-monsoon season, which could lead to higher atmospheric concentrations. S5P/TROPOMI $X_{C_{4}}$ and $X C O$ were validated from November 2017 to September 2020 against the TCCON and Infrared Working Group of the Network for the Detection of Atmospheric Composition Change (NDACC-IRWG) observations [21].

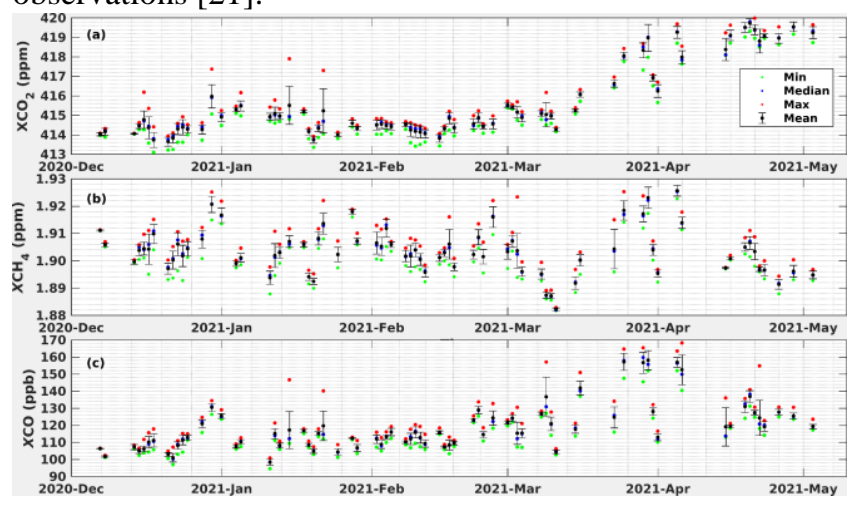

Figure 3. The daily maximum, minimum, median and average values with \pm 1 standard deviation of gaseous species, a) $\left.\mathrm{XCO}_{2}, b\right) \mathrm{XCH}_{4}$ and c) $\mathrm{XCO}$ during the study period.

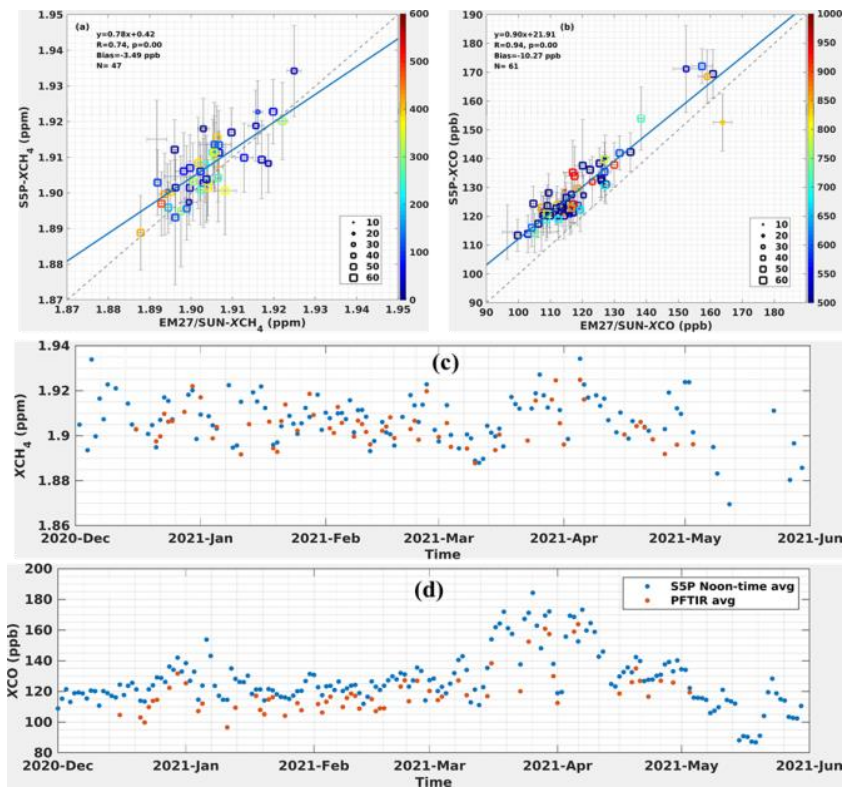

Figure 4. Figure 4. a) $\mathrm{XCH}_{4}$ and b) $\mathrm{XCO}$ comparison between S5p/TROPOMI and EM27/SUN. The color bar and the size of the squares represent the number of S5P total column observations and the number of EM27/SUN ground observations at the same time. The horizontal and vertical bar is one standard deviation of S5P and EM27/SUN observations. c) Time series of $\mathrm{XCH}_{4}$ between EM27/SUN against TROPOMI XCO d) time series of XCO same as (c). 
Validation of Sentinel-5p/TROPOMI: In this work, a comparison of S5P/TROPOMI retrieved $\mathrm{XCH}_{4}$ and $\mathrm{XCO}$ is performed with respect to the EM27/SUN spectrometer retrievals. Further, we compare the atmospheric column averaged dry-air mole fractions of $\mathrm{XCH}_{4}$ and $\mathrm{XCO}$ retrieved from EM27/SUN sensor with S5P/TROPOMI retrievals at Shadnagar, sub-urban region of Telangana, India. During this study period, spatially and temporally collocated $\mathrm{XCH}_{4}$ and $X \mathrm{CO}$ data from S5p/TROPOMI using a $100 \mathrm{~km}$ radius from the observational site and \pm 1 hour as criteria only considered for the comparison. The number of samples for ground observation, S5P CH 4 and S5P CO range 3-60, 3-686, and 1967. The resultant comparison is shown in figure 4 (a-d) respectively for $\mathrm{XCH}_{4}$ and $\mathrm{XCO}$.

\begin{tabular}{|l|l|l|l|l|l|}
\hline Parameter & Mean & $\pm 1 \sigma$ & Min & Max & Median \\
\hline $\begin{array}{l}X \mathrm{CO}_{2} \\
(\mathrm{ppm})\end{array}$ & 415.57 & 1.89 & 413.09 & 420.57 & 414.78 \\
\hline $\begin{array}{l}X \mathrm{CH}_{4} \\
(\mathrm{ppm})\end{array}$ & 1.904 & 0.008 & 1.882 & 1.931 & 1.902 \\
\hline $\begin{array}{l}X \mathrm{CO} \\
(\mathrm{ppb})\end{array}$ & 118.74 & 13.85 & 94.62 & 170.40 & 114.95 \\
\hline
\end{tabular}

Table 2. Statistics of $\mathrm{XCO}_{2}, \mathrm{XCH}_{4}$, and $\mathrm{XCO}$ during the study period.

The average value of $\mathrm{XCH}_{4}$ for EM27 and S5P were found $1.903 \pm 0.01$ and $1.907 \pm 0.01$. The bias of EM27/SUN w.r.t S5P was observed $-3.487 \mathrm{ppb}(-0.18 \%)$ with the co-located observations. (EM27-S5P)/S5P).

It is clear that atmospheric $\mathrm{XCH}_{4}$ and $\mathrm{XCO}$ showed a good correlation with correlation coefficients (r) of 0.75 and 0.94 respectively. During the comparison period, TROPOMI retrieved $\mathrm{XCH}_{4}$ and $\mathrm{XCO}$ are following ground-based EM27/SUN spectrometer retrievals (Figure 4c-d). Thus, we report a good agreement between retrievals of atmospheric column-averaged dry-air mole fractions of $\mathrm{XCH}_{4}$ and $\mathrm{XCO}$ from EM27/SUN and S5P/TROPOMI retrievals.

The average of XCO for EM27/SUN and S5P/TROPOMI CO was $119.46 \pm 14.57$ and $129.72 \pm 14.01$ with the co-located while the bias was observed $-10.26(-7.91 \%)$. The bias and ' $r$ ' values are computed under the varied sampling radius as summarized in table 3. The EM27/SUN $X_{C H}$ and $X C O$ exhibit a negative bias of $0.001 \mathrm{ppm}$ and $10.22 \mathrm{ppb}$ with S5P/TROPOMI retrievals respectively.

\begin{tabular}{|l|l|l|l|l|l|l|}
\hline Parameter & $\begin{array}{l}\text { Radius } \\
(\mathrm{km})\end{array}$ & $\mathrm{N}$ & $\mathrm{R}$ & $\begin{array}{l}\text { Bias } \\
(\mathrm{ppb})\end{array}$ & $\begin{array}{l}\text { EM27 } \\
(\mu \pm 1 \sigma)\end{array}$ & $\begin{array}{l}\text { S5P } \\
(\mu \pm 1 \sigma)\end{array}$ \\
\hline $\mathrm{CH}_{4}$ & 50 & 45 & 0.79 & -2.58 & $\begin{array}{l}1.903 \pm \\
0.01\end{array}$ & $\begin{array}{l}1.905 \\
\pm 0.01\end{array}$ \\
\hline $\mathrm{CH}_{4}$ & 20 & 36 & 0.79 & -3.10 & $\begin{array}{l}1.902 \pm \\
0.01\end{array}$ & $\begin{array}{l}1.905 \\
\pm 0.01\end{array}$ \\
\hline $\mathrm{CO}$ & 50 & 61 & 0.94 & -10.22 & $\begin{array}{l}119.46 \\
\pm \\
14.57\end{array}$ & $\begin{array}{l}129.68 \\
\pm \\
13.77\end{array}$ \\
\hline $\mathrm{CO}$ & 20 & 56 & 0.94 & -9.00 & $\begin{array}{l}120.12 \\
\pm \\
14.72\end{array}$ & $\begin{array}{l}129.13 \\
\pm \\
13.88\end{array}$ \\
\hline
\end{tabular}

Table 3. Observed Validation of S5p considering different spatial observations area. $N$ and $R$ show the number of colocated days and correlation coefficient.

\section{CONCLUSION}

In this study, we demonstrated first-hand columnar $\mathrm{XCO}_{2}, \mathrm{XCH}_{4}$, and $\mathrm{XCO}$ using the EM27/SUN spectrometer data from $7^{\text {th }}$ December 2020 to $3^{\text {rd }}$ May 2021. During this study period, the dry air column was observed to be in the range of (0.9856-0.9924) indicating the stability of the EM27/SUN spectrometer. The $X \mathrm{CO}_{2}, X_{C_{4}}$, and $X \mathrm{CO}$ exhibited mild diurnal variation. The retrieved columnar concentrations also observed clear seasonality from winter to pre-monsoon. Further, the present study evaluated Sentinel 5P/TROPOMI retrieved $\mathrm{XCH}_{4}$ and $\mathrm{XCO}$ against EM27/SUN spectrometer retrievals and found very good agreement with ' $r$ ' values of 0.74 and 0.94 respectively. The biases between EM27/SUN and S5P/TROPOMI retrieved $\mathrm{XCH}_{4}$ and $X \mathrm{CO}$ are $-3.4872 \mathrm{ppb} \quad(-0.1829 \%)$ and $-10.2670 \quad(-7.9141 \%)$ respectively, meeting mission requirements of bias \pm precision of less than $1.5 \% \pm 1 \%$ for $\mathrm{CH}_{4}$ and $15 \% \pm 10 \%$ for $\mathrm{CO}$. Thus, the present study demonstrated the retrieval of $X \mathrm{CO}_{2}, X \mathrm{CH}_{4}$, and $X \mathrm{CO}$ while meeting the COCCON observations along with satellite validation.

\section{ACKNOWLEDGMENT}

Authors sincerely thank Dr. Raj Kumar, Director, NRSC for his kind encouragement and support to carry out this work. The authors would like to acknowledge COCCON for PROFFAST software and extend their guidance in retrieving the data. We also thank the European Space Agency for the Copernicus Sentinel-5 Precursor mission (S5P/TROPOMI) data.

\section{REFERENCES}

[1] J. G. CANADELL ET AL., "MULTI-DECADAL INCREASE OF FOREST BURNED AREA IN AUSTRALIA IS LINKED TO CLIMATE CHANGE," NAT. COMMUN., VOL. 12, NO. 1, P. 6921, DEC. 2021, DOI: 10.1038/s41467-021-27225-4. 
$>$ REPLACE THIS LINE WITH YOUR MANUSCRIPT ID NUMBER (DOUBLE-CLICK HERE TO EDIT) <

[2] T. F. Stocker et al., "Working Group I Contribution to the Fifth Assessment Report of the Intergovernmental Panel on Climate Change," p. 14.

[3] "Annual Reports Year wise (Ministry) $\mid$ Government of India | Ministry of Power." https://powermin.gov.in/sites/default/files/uploads/Annua 1_Report_2010-11_English.pdf (accessed Jan. 31, 2022).

[4] J. Huang, H. Yu, X. Guan, G. Wang, and R. Guo, "Accelerated dryland expansion under climate change," Nat. Clim. Change, vol. 6, no. 2, pp. 166-171, Feb. 2016, doi: $10.1038 /$ nclimate2837.

[5] N. US Department of Commerce, "Global Monitoring Laboratory - Carbon Cycle Greenhouse Gases." https://gml.noaa.gov/ccgg/trends_ch4/ (accessed Jan. 31, 2022).

[6] G. Sreenivas et al., "Seasonal and annual variations of $\mathrm{CO} 2$ and CH4 at Shadnagar, a semi-urban site," Sci. Total Environ., vol. 819, p. 153114, May 2022, doi: 10.1016/j.scitotenv.2022.153114.

[7] P. J. Crutzen and P. H. Zimmermann, "The changing photochemistry of the troposphere," Tellus A, vol. 43, no. 4, pp. 136-151, Aug. 1991, doi: 10.1034/j.16000870.1991.00012.x.

[8] T. Yokota et al., "Global Concentrations of $\mathrm{CO} 2$ and CH4 Retrieved from GOSAT: First Preliminary Results," SOLA, vol. 5, pp. 160-163, 2009, doi: 10.2151/sola.2009041.

[9] Y. Yoshida et al., "Improvement of the retrieval algorithm for GOSAT SWIR XCO\&lt;sub\&gt;2\&lt;/sub\&gt; and XCH\&lt;sub\&gt; 4 \&lt;/sub\&gt; and their validation using TCCON data," Atmospheric Meas. Tech., vol. 6, no. 6, pp. 1533-1547, Jun. 2013, doi: 10.5194/amt-6-15332013.

[10] P. J. Rayner and D. M. O'Brien, “The utility of remotely sensed $\mathrm{CO}_{2}$ concentration data in surface source inversions," Geophys. Res. Lett., vol. 28, no. 1, pp. 175178, Jan. 2001, doi: 10.1029/2000GL011912.

[11] A. Kuze, H. Suto, M. Nakajima, and T. Hamazaki, "Thermal and near infrared sensor for carbon observation Fourier-transform spectrometer on the Greenhouse Gases Observing Satellite for greenhouse gases monitoring," Appl. Opt., vol. 48, no. 35, p. 6716, Dec. 2009, doi: 10.1364/AO.48.006716.

[12] H. Suto et al., "Thermal and near-infrared sensor for carbon observation Fourier transform spectrometer-2 (TANSO-FTS-2) on the Greenhouse gases Observing SATellite-2 (GOSAT-2) during its first year in orbit," Atmospheric Meas. Tech., vol. 14, no. 3, pp. 2013-2039, Mar. 2021, doi: 10.5194/amt-14-2013-2021.

[13] C. Frankenberg et al., "The Orbiting Carbon Observatory (OCO-2): spectrometer performance evaluation using pre-launch direct sun measurements," Atmospheric Meas. Tech., vol. 8, no. 1, pp. 301-313, Jan. 2015, doi: 10.5194/amt-8-301-2015.

[14] A. Eldering et al., "The Orbiting Carbon Observatory-2: First 18 months of Science Data Products," Gases/Remote Sensing/Validation and Intercomparisons, preprint, Sep. 2016. doi: 10.5194/amt-2016-247.
[15] J. P. Veefkind et al., "TROPOMI on the ESA Sentinel-5 Precursor: A GMES mission for global observations of the atmospheric composition for climate, air quality and ozone layer applications," Remote Sens. Environ., vol. 120, pp. 70-83, May 2012, doi:

10.1016/j.rse.2011.09.027.

[16] D. Wunch et al., "The Total Carbon Column Observing Network," Philos. Trans. R. Soc. Math. Phys. Eng. Sci., vol. 369, no. 1943, pp. 2087-2112, May 2011, doi: 10.1098/rsta.2010.0240.

[17] M. Frey et al., "Building the COllaborative Carbon Column Observing Network (COCCON): long-term stability and ensemble performance of the EM27/SUN Fourier transform spectrometer," Atmospheric Meas. Tech., vol. 12, no. 3, pp. 1513-1530, Mar. 2019, doi: 10.5194/amt-12-1513-2019.

[18] M. Gisi, F. Hase, S. Dohe, T. Blumenstock, A. Simon, and A. Keens, "XCO\&1t;sub\&gt;2\&lt;/sub\&gt;measurements with a tabletop FTS using solar absorption spectroscopy," Atmospheric Meas. Tech., vol. 5, no. 11, pp. 2969-2980, Nov. 2012, doi: 10.5194/amt-5-29692012.

[19] M. K. Sha et al., "Intercomparison of low- and highresolution infrared spectrometers for ground-based solar remote sensing measurements of total column concentrations of CO\&lt;sub\&gt;2\&lt;/sub\&gt; CH\&lt;sub\&gt;4\&lt;/sub\&gt; and CO," Atmospheric Meas. Tech., vol. 13, no. 9, pp. 4791-4839, Sep. 2020, doi: 10.5194/amt-13-4791-2020.

[20] European Space Agency, "TROPOMI Level 2 Carbon Monoxide Total Column." European Space Agency, 2021. doi: 10.5270/S5P-bj3nry0.

[21] M. K. Sha et al., "Validation of Methane and Carbon Monoxide from Sentinel-5 Precursor using TCCON and NDACC-IRWG stations," Gases/Remote Sensing/Validation and Intercomparisons, preprint, Apr. 2021. doi: 10.5194/amt-2021-36.

[22] M. Mermigkas et al., "FTIR Measurements of Greenhouse Gases over Thessaloniki, Greece in the Framework of COCCON and Comparison with S5P/TROPOMI Observations," Remote Sens., vol. 13, no. 17, p. 3395, Aug. 2021, doi: 10.3390/rs13173395.

[23] European Space Agency, "TROPOMI Level 2 Methane Total Column.” European Space Agency, 2021. doi: 10.5270/S5P-31cdqiv.

[24] "Copernicus Sentinel-5P (processed by ESA), 2019, TROPOMI Level 2 Methane Total Column. Version 01." European Space Agency, 2019. doi: 10.5270/S5P3p6lnwd.

[25] "Copernicus Sentinel-5P (processed by ESA), 2018, TROPOMI Level 2 Carbon Monoxide Total Column. Version 01.” European Space Agency, 2018. doi: 10.5270/S5P-1hkp7rp.

[26] J. H. Seinfeld and S. N. Pandis, "Atmospheric Chemistry and Physics: From Air Pollution to Climate Change," p. 1149. 
> REPLACE THIS LINE WITH YOUR MANUSCRIPT ID NUMBER (DOUBLE-CLICK HERE TO EDIT) <

Vijay K. Sagar and Mahesh $\mathbf{P}$ are in Atmospheric Chemistry Division of Earth and Climate Sciences Area (ECSA), National Remote Sensing Centre (NRSC), Indian Space Research Organization (ISRO), Hyderabad, 500037, Telangana, India and (vijaykmsagar@gmail.com; Corresponding author: Mahesh P, mahi952@gmail.com).

Mahesh P and Rajan K.S (rajan@iiit.ac.in). are with the Lab for Spatial Informatics (LSI), International Institute of Information Technology (IIIT), Hyderabad-500032, India.

Mahalakshmi D.V is with Land and Atmospheric Physics

Division-ECSA,

NRSC, ISRO

(mahameteorology@gmail.com).

Sesha Sai M.V.R is with ECSA, NRSC, ISRO, Hyderabad, 500037, Telangana, India (seshasaimvr@rediffmail.com).

Frank Hase and Darko Dubravica are with Karlsruhe Institute of Technology (KIT), Institute for Meteorology and Climate Research (IMK-ASF), Karlsruhe (frank.hase@kit.edu, darko.dubravica@kit.edu)

Mahesh Kumar Sha is with Royal Belgian Institute for Space Aeronomy (BIRA-IASB), Brussels, Belgium (mahesh.sha@aeronomie.be) 